\title{
Implications of Land Use Land Cover Change and Climate Variability on Future Prospects of Beef Cattle Production in the Lake Victoria Basin
}

\author{
Japhet Joel Kashaigili1 ${ }^{*}$, Emmanuel Zziwa ${ }^{2,3}$, Siwa Ernest ${ }^{4}$, Emma Laswai1, \\ Bernard Musana Segatagara5, Denis Mpairwe², Reuben Mpuya Joseph Kadigi', \\ Cyprian Ebong5, Samuel Katambi Mugasi6, Germana Henry Laswai', Mutimura Mupenzi' \\ Polycarp Jacob Ngowi ${ }^{1}$, Ibrahim Lwaho Kadigi ${ }^{1}$ \\ ${ }^{1}$ Sokoine University of Agriculture, Morogoro, Tanzania \\ ${ }^{2}$ Makerere University, Kampala, Uganda \\ ${ }^{3}$ Association for Strengthening Agricultural Research in Eastern and Central Africa (ASARECA), Entebbe, Uganda \\ ${ }^{4}$ Tanzania Forestry Research Institute (TAFORI), Morogoro, Tanzania \\ ${ }^{5}$ Rwanda Agriculture Board (RAB), Kigali, Rwanda \\ ${ }^{6}$ National Agricultural Advisory Services, (NAADS), Kampala, Uganda \\ Email: "jkashaigili@gmail.com
}

Received 24 August 2015; accepted 26 December 2015; published 29 December 2015

Copyright (C) 2015 by authors and Scientific Research Publishing Inc.

This work is licensed under the Creative Commons Attribution International License (CC BY). http://creativecommons.org/licenses/by/4.0/

c) (i) Open Access

\section{Abstract}

This paper presents the lessons learnt from a research project titled "Improving Beef Cattle Productivity for Enhanced Food Security and Efficient Utilization of Natural Resources in the Lake Victoria Basin" which includes Tanzania, Uganda and Rwanda. The key focus is on the implications of land use land cover change and climate variability on the future prospects of beef cattle production in this region. The study utilizes information and data from natural resources and climate components to deduce the impact of land use and land cover changes on climate variability. Additional analysis is conducted to summarize the land use and land cover data to carry out analysis on climate data using the Mann-Kendal test, linear regression and moving averages to reveal patterns of change and trends in annual and seasonal rainfall and temperature. The findings reveal that the study areas of Rwanda, Uganda and Tanzania in the Lake Victoria Basin (LVB) have changed over time following land cover manipulations and land use change, coupled with climate variability. The grazing land has been converted to agriculture and settlements, thereby reducing cattle grazing land which is the cheapest and major feed source for ruminant livestock production. Although

${ }^{*}$ Corresponding author.

How to cite this paper: Kashaigili, J.J., et al. (2015) Implications of Land Use Land Cover Change and Climate Variability on Future Prospects of Beef Cattle Production in the Lake Victoria Basin. American Journal of Climate Change, 4, 461-473.

http://dx.doi.org/10.4236/ajcc.2015.45037 
the cattle population has been on the increase in the same period, it has been largely attributed to the fact that the carrying capacity of available grazing areas had not been attained. The current stocking rates in the LVB reveal that the rangelands are greatly overstocked and overgrazed with land degradation already evidenced in some areas. Climate variability coupled with a decrease in grazing resources is driving unprecedented forage scarcity which is now a major limiting factor to cattle production. Crop cultivation and settlement expansion are major land use types overtaking grazing lands; therefore the incorporation of crop residues into ruminant feeding systems could be a feasible way to curtail rangeland degradation and increase beef cattle production.

\title{
Keywords
}

\author{
Beef Cattle Production, Climate Variability, Crop Residues, Land Use Land Cover Change, Lake \\ Victoria Basin
}

\section{Introduction}

More than $60 \%$ of the Lake Victoria Basin (LVB) is covered by rangelands and livestock production which is a key economic activity in the Basin particularly in Rwanda, Tanzania and Uganda [1]. About 20\%, 36\% and 40\% of Uganda, Tanzania and Rwanda's cattle herds respectively are located in the LVB [2]-[5]. Because of the proximity to permanent water sources, the LVB also supports seasonal influxes in cattle populations from other regions especially during the dry seasons. More than $99 \%$ of the ruminants in the LVB are kept by smallholder farmers; and the over reliance of natural resources, which are constantly depreciating makes the inhabitants of the LVB the poorest in the region [1]. The increasing human population in the basin, increased cultivation in rangelands and climate variability are exerting unprecedented pressures on land resources that jeopardize the ability to sustain livestock production and the environment.

The majority of beef cattle keepers in the rangelands of LVB mainly practice extensive production system which involves the grazing of cattle on natural pastures in either sedentary or migratory patterns. The system is characterized by overgrazing, low off-take rates, low technical efficiency measures in terms of calving rates, higher mortality rates and soil degradation [1] [6]. Stock migration, the major practices that are used to offset the challenges of overgrazing and related natural degradation is almost phasing out due to increased settlements and cultivation and thus exacerbating degradation of rangelands.

The growth in human population and subsequent urbanization are creating increasing demand for livestock products, thereby forcing production to more than double by 2030, if the demand is to be met [7]. This demand will take place at a time when the traditional grazing resources are diminishing [8]. Despite the immense invasion of traditional grazing resources with cultivation, there is limited knowledge among farmers in the utilization of crop residues in animal feeding [9]. Understanding the extent of land use and cover changes in the LVB of Rwanda, Tanzania and Uganda is an important precept in informing policy makers and devising sustainable beef production practices and integrating with other land use practices.

\section{Material and Methods}

\subsection{Description of the Study Areas}

The study was conducted in the Lake Victoria Basin (Figure 1) in three countries of Rwanda, Tanzania and Uganda which have a high number of livestock in the Basin. Four districts in Uganda (Isingiro, Rakai, Lyantonde and Lwengo), two in Tanzania (Ilemela and Magu) and two in Rwanda (Nyagatare, Gatsibo, Rwamagana, Kayonza, Ngoma and Kirehe) were included in the study. Geographically, the study districts are located along the Equator between longitudes $30^{\circ} 00^{\prime} \mathrm{E}$ and $34^{\circ} 00^{\prime} \mathrm{E}$, and latitudes $0^{\circ} 00^{\prime} \mathrm{S}$ and $4^{\circ} 00^{\prime} \mathrm{S}$.

\subsection{Topography and Climate of the Study Areas}

Following their altitudinal differences and their closeness to the equator, the study areas experience varied climatic conditions. For example, Rwanda has a tropical highland climate, with a temperature profile strongly de- 
pendent on elevation and receives bimodal rainfall distribution (from mid-September to mid-December and from March to May) dominated by the progression of the Inter-Tropical Convergence Zone (ITCZ). Nevertheless, the study districts in Rwanda fall under semi-arid climate conditions (owing to its position in the rainy shadow of the western highlands-typical for central and eastern part of the country) with total annual rainfall averaging to about $1000 \mathrm{~mm}$ and annual mean daily temperature of about $22^{\circ} \mathrm{C}$. The study districts in Tanzania receive rainfall averaging to about $800 \mathrm{~mm}$ per annum with the annual mean temperature ranging between $24^{\circ} \mathrm{C}$ and $30^{\circ} \mathrm{C}$. In Uganda, the areas receive on average rainfall ranging between 750 and $1200 \mathrm{~mm}$ annually. Rakai District which is located just at the Equator receives more rains as compared to the rest (Table 1).

\subsection{Methods}

\subsubsection{Land Use and Land Cover Change Analyses}

The study pooled land use and cover change analyses of the LVB for Uganda (1984, 2000 and 2013), Tanzania

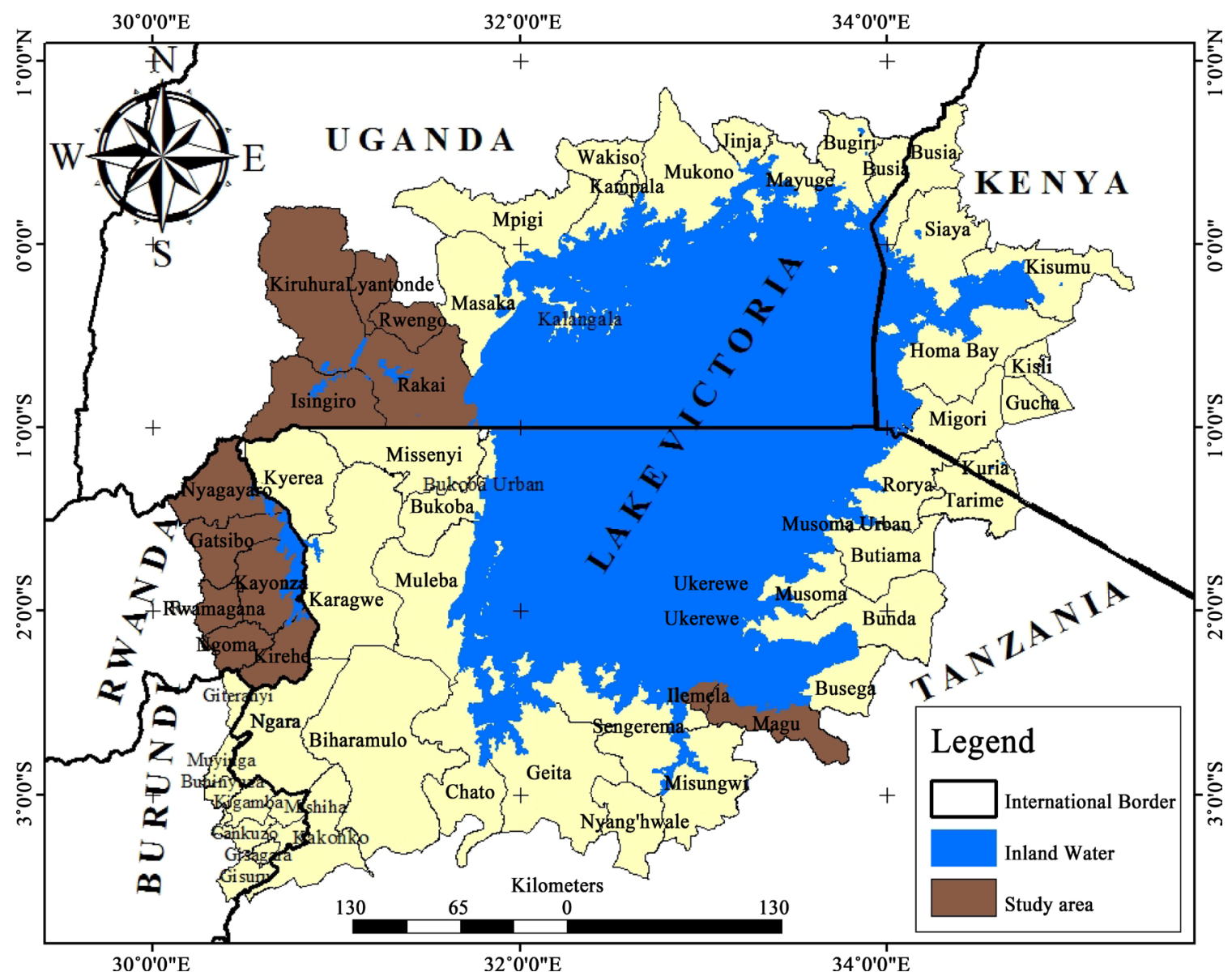

Figure 1. Map showing the Lake Victoria Basin.

Table 1. Altitudes, rainfall and temperature in the study areas of Uganda, Rwanda and Tanzania.

\begin{tabular}{cccccc}
\hline Country & Study districts & $\begin{array}{c}\text { Elevation } \\
\text { (m.a.sl) }\end{array}$ & Rainfall pattern & $\begin{array}{c}\text { Mean annual } \\
\text { rainfall range } \\
(\mathbf{m m})\end{array}$ & $\begin{array}{c}\text { Annual mean } \\
\text { temperature range } \\
\left({ }^{\circ} \mathbf{C}\right)\end{array}$ \\
\hline Tanzania & Magu, Ilemela & $<1000$ & Bimodal (OND \& MAM) & $700-1000$ & $24-30$ \\
\multirow{2}{*}{ Rwanda } & $\begin{array}{c}\text { Nyagatare, Gatsibo, Rwamagana, } \\
\text { Kayonza, Ngoma and Kirehe }\end{array}$ & $<1000$ & Bimodal (SOND \& MAM) & $1000-1150$ & $22-24$ \\
& $\begin{array}{c}\text { Uganda } \\
\text { Isingiro, Rakai, Lyantonde and Lwengo }\end{array}$ & $<1000$ & Bimodal (MAM \& SON) & $750-1200$ & $10-28$ \\
\hline
\end{tabular}


(1980, 2000 and 2010) and Rwanda (1990, 2000 and 2010) that were analysed from satellite images (Landsat TM and EMT+). The detailed methodologies for land use land cover (LULC) assessment could be found in [8] [10] and [11] for the countries of Uganda, Tanzania and Rwanda respectively and thus detailed methods are not repeated here. However, this study uses some information from these reports to augment its own findings.

\subsubsection{Climatic Data Analysis}

Climatic data (temperature and rainfall) were obtained from the representative stations with good records of at least 30 years in the three study sites, and analysed to understand variability and changes (CVC) in climate over the time. Climate data were categorized into seasons and their trends analysed using Mann-Kendal test [12]. The trends were evaluated using normalized test $\mathrm{Z}$ statistics at 95\% confidence level $(\mathrm{p}=0.05)$. Also linear regression and moving averages in annual values were applied.

\section{Results and Discussion}

\subsection{Land Use Land Cover and Population Changes in the LVB}

Land use and cover maps in the study areas of Uganda, Rwanda and Tanzania show a conspicuous reduction in grazing areas and increase in cultivated areas over the last twenty years (Figure 2; Figures 3(a)-(c)). Grazing areas reduced by 18.5\%, 25.5\% and 30.4\% in Uganda, Rwanda and Tanzania between 1986 and 2013,1990 and 2010 and 1984 and 2010 respectively. In the same period, cultivated areas increased by 11.5\%, 24.9\% and 12.2\% of the total study area in Uganda, Rwanda and Tanzania respectively. The overall reduction in natural vegetation cover (grasslands, bushland, woodland, forests and riverine vegetation) and increase in cultivated areas signifies that cultivation is the major land use type decimating grazing areas. In Tanzania, 65.3\% of riverine vegetation, the major grazing area, was converted into cultivation and settlement between 1986 and 2000; and 46.9\% converted between 2000 and 2010 to the same types of use [10]. [8] also reported similar trends in Uganda with 5.8\%

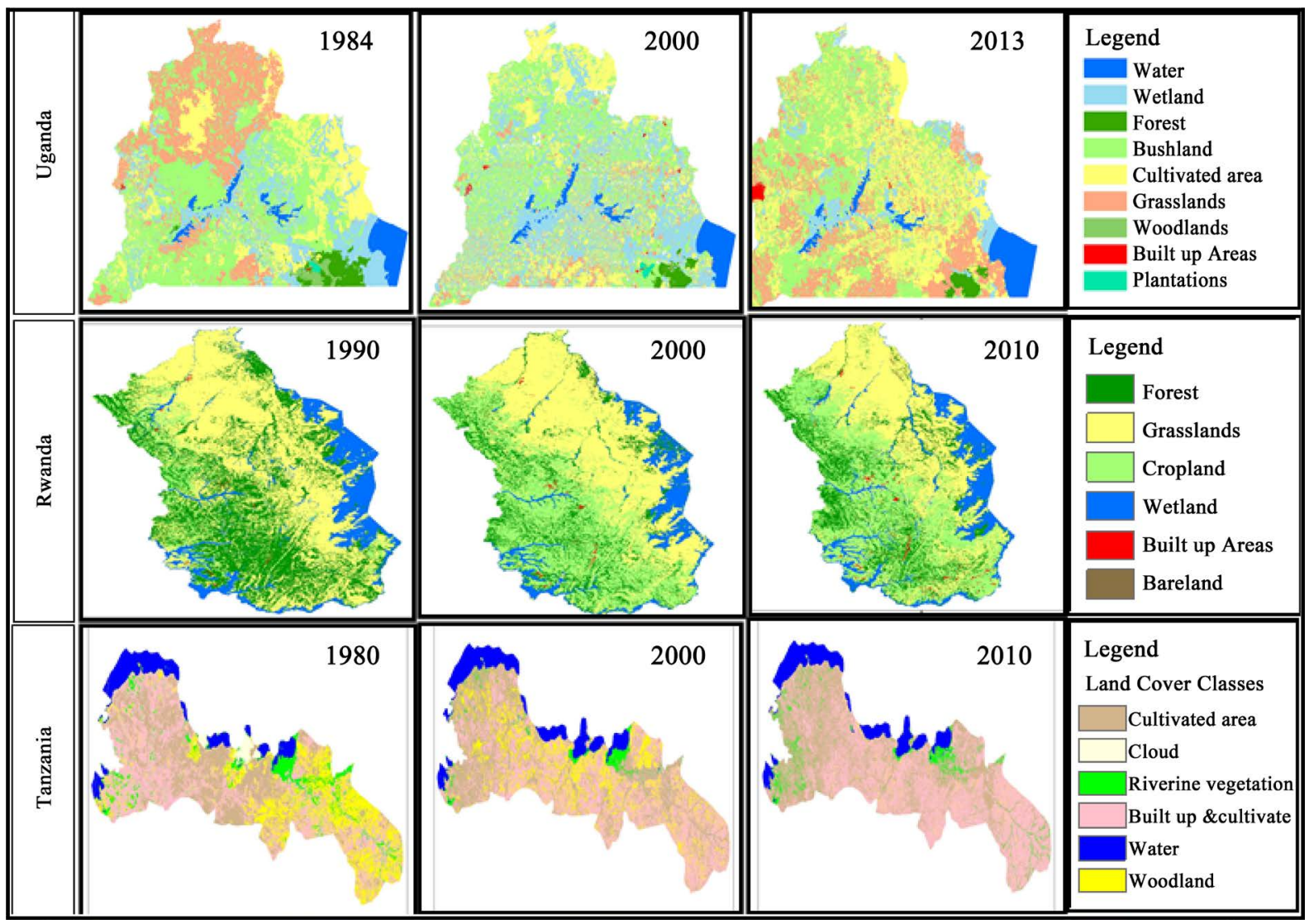

Figure 2. Land use and cover change maps for Lake Victoria Basin study areas in Uganda, Rwanda and Tanzania. 


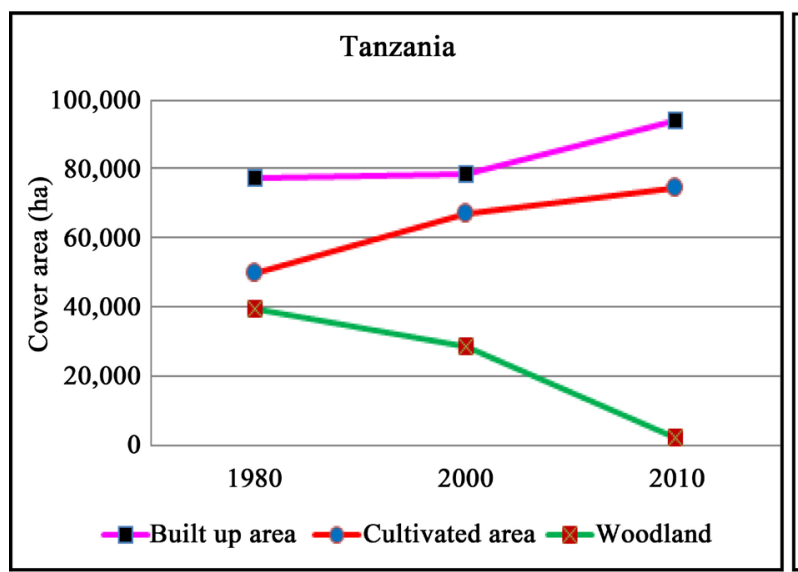

(a)

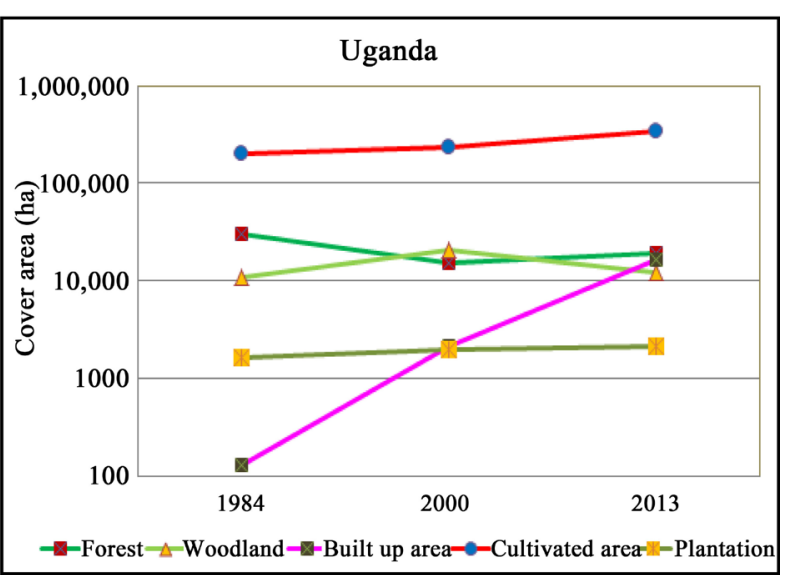

(b)

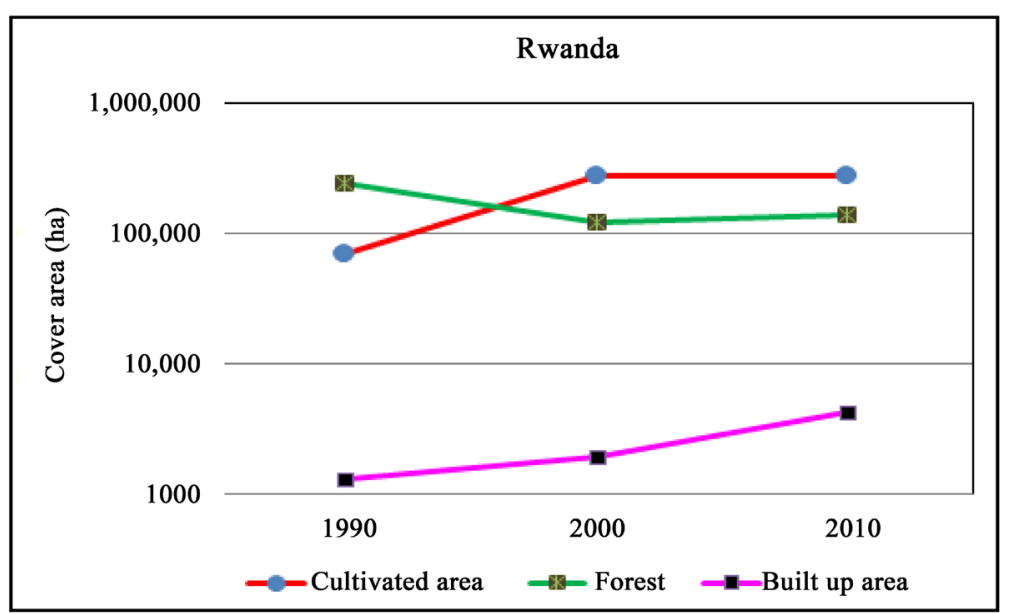

(c)

Figure 3. Comparison between different covers with time for the three study areas in the LVB for the three countries of Tanzania, Rwanda and Uganda.

of grassland converted to cultivation between 1986 and 2000 and 34.8\% grasslands converted to cultivation between 2000 and 2013. In Rwanda, 15\% of grazing areas were converted into other use types between 1990 and 2000 while 12.4\% were converted between 2000 and 2010. Noticeable increase in forest areas were also revealed in later period than the former for both study areas in Rwanda and Uganda. The increase in forest in Rwanda for the period 2000-2010 has been due to the regeneration caused by stopping encroachment in the Akagera National Parks that constitutes a larger part of the study area. The stopping encroachment was an outcome of end of emergency period in Rwanda, where the encroachment in the newly redefined boundaries of the Akagera National parks started to be controlled with electrical fences and ranger patrol. Available information revealed that over 50\% of the Akagera National Park was encroached during the emergency period.

The tremendous decline in grazing areas may be greatly attributed to high increase in human population within the basin (Figure 4(a), Figure 4(b); Table 2). Between 1986 and 2013, the human population in five districts of Uganda under this study increased by $61.2 \%$ from 963,456 to 1,552,900. The increasing population creates more pressure on land for settlement as well as cultivation to produce more food. Similar trends in population growth around the Lake Victoria Basin have been reported by [1] that the LVB is the most densely populated and with the highest growth rates in the region.

The decline of wetland, bushland and grasslands areas has caused the decrease in pasture as the extensive production system, which is practiced by beef cattle keepers in the study area, is heavily dependent on natural grasslands as the source of feed for cattle. Following increase in human population (highest in Africa) in Rwanda, most of the pastureland areas have been converted to agriculture thus shrinking the available pastureland for beef cattle production. With the extreme population density, the mid and high-altitude, farmers had 


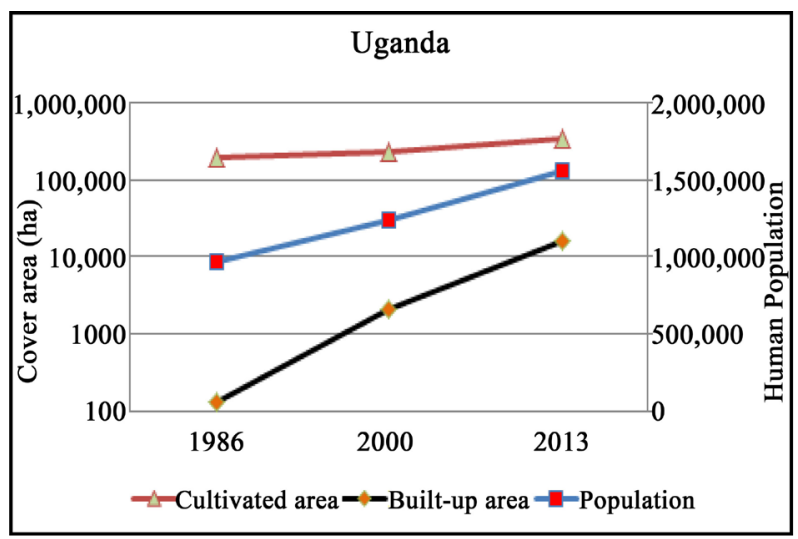

(a)

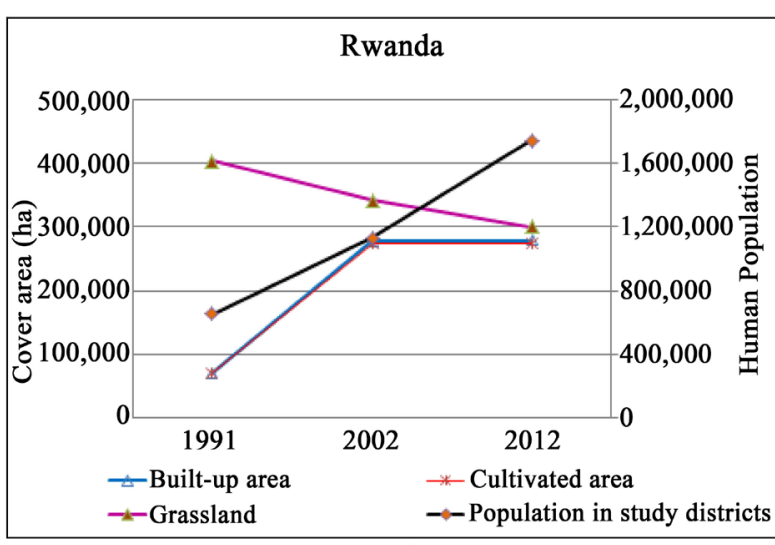

(b)

Figure 4. Comparison between cultivated area, built-up area and human population with time for the three study areas in the LVB for the three countries of Tanzania, Rwanda and Uganda.

Table 2. Comparison between human population versus settlement area, cultivated area and pastureland for Magu and Ilemela Districts in Tanzania.

\begin{tabular}{cccc}
\hline Category & \multicolumn{2}{c}{ Census year } & \multirow{2}{*}{ Change } \\
\cline { 2 - 3 } & $\mathbf{2 0 0 2}$ & $\mathbf{2 0 1 2}$ & 79,159 \\
Human Population in Ilemela District & 263,842 & 343,001 & 54,733 \\
Human Population in Magu District & 245,026 & 299,759 & 15,899 \\
Settlement area & 78,328 & 94,227 & 7178 \\
Cultivated area & 67,266 & 74,444 & $-22,736$ \\
\hline Pastureland (grassland, bushland, riverine vegetation) & 33,754 & 11,018 & \\
\hline
\end{tabular}

started exploring the possibility of immigrating to the lower eastern savanna and thus introducing more crop based farm management in this area. The government induced some changes in the land use by promoting rice production in the swamps which attracted more crop based farmers, while animal movement was controlled with zero grazing in mid and high altitude, such policy started to be enforced around 2005. The reduction in grazing area has resulted to inadequate level of nutrition which is the major limiting factor to beef cattle production, poor performance in reproduction and weight gain.

\subsection{Climate Variability}

The climate of the study areas in the Lake Victoria Basin was found to vary with time. Table 3 and Table 4 present trends of seasonal and annual rainfall and temperature over time in Tanzania and Uganda study sites. A similar analysis was not possible for Rwanda due to lack of long time series of monthly rainfall and temperature, nevertheless the average historical monthly rainfall and temperature for different periods obtained from online climate databases are presented.

The results on trend analysis for both rainfall and temperature revealed variability between the periods under investigation (Table 3 and Table 4). The slopes of the trend lines for short rains; September, October and November (SON) and long rains; March, April and May (MAM) at the study stations in Tanzania and Uganda revealed a declining trend with the exception of Mwanza airport station. The analysis using linear regression and 5 years moving averages in Uganda revealed increase in MAM rainfall and decrease in SON (Figure 5). Such variations might be attributable to a number of factors including variations in the micro-climatic conditions but also to the methods of analysis. The use of moving averages tries to smoothen out the variations between individual years which might be missing in other approaches. Although the seasonal rainfall for both SON and MAM revealed increase and decrease in amount over time respectively, the test statistics was not significant at $(p=0.05)$. It is important noting that despite the insignificance as a result of statistical analysis, there is generally a mild decline or increase in amount of seasonal rainfall over time around the study area. 
Table 3. Summary of test statistic (Z) in annual and seasonal rainfall amounts at Ukerewe and Mwanza Airport Meteorological station (=5\%), Tanzania.

\begin{tabular}{cccccccccc}
\hline \multirow{2}{*}{ Station name } & \multirow{2}{*}{ Parameter } & \multicolumn{2}{c}{ Record length } & \multicolumn{5}{c}{ Trends for respective record periods } \\
\cline { 3 - 9 } & & From & To & $\begin{array}{c}\text { SON } \\
\text { (short rains) }\end{array}$ & $\begin{array}{c}\text { DJF } \\
\text { (transition) }\end{array}$ & $\begin{array}{c}\text { MAM } \\
\text { (long rains) }\end{array}$ & JJA \\
(dry season) & Annual \\
\hline \multirow{2}{*}{ Ukerewe Met. } & & 1970 & 2000 & -0.17 & 0.14 & -0.20 & -1.75 & -0.71 \\
& Rainfall & 1969 & 1996 & 0.25 & 0.75 & 0.21 & 0.88 & 0.28 \\
Mwanza airport & Maximum temp. & 1970 & 1992 & -1.20 & 1.24 & 0.05 & 0.29 & 1.93 \\
& Minimum temp. & 1970 & 1994 & 0.82 & 1.43 & -0.58 & 1.19 & 1.45 \\
\hline
\end{tabular}

Table 4. Summary of test statistic (Z) in annual and seasonal rainfall amounts at Uganda case study, $(\alpha=5 \%)$.

\begin{tabular}{cccccccccc}
\hline & & \multicolumn{3}{c}{ Record length } & \multicolumn{5}{c}{ Trends for respective record periods } \\
\cline { 3 - 9 } Station name & Parameter & From & To & $\begin{array}{c}\text { SON } \\
\text { (short rains) }\end{array}$ & $\begin{array}{c}\text { DJF } \\
\text { (transition) }\end{array}$ & $\begin{array}{c}\text { MAM } \\
\text { (long rains) }\end{array}$ & $\begin{array}{c}\text { JJA } \\
\text { (dry season) }\end{array}$ & $\begin{array}{c}\text { Annual } \\
\text { Unanda Met. station }\end{array}$ \\
\cline { 3 - 10 } & Rainfall & 1963 & 2008 & -0.30 & -0.83 & -0.17 & -0.09 & 0.03 \\
& Maximum temp. & 1960 & 2002 & 4.12 & 3.04 & 3.34 & 3.70 & 4.95 \\
& Minimum temp. & 1960 & 2002 & 3.89 & 4.15 & 5.08 & 4.17 & 4.51 \\
\hline
\end{tabular}

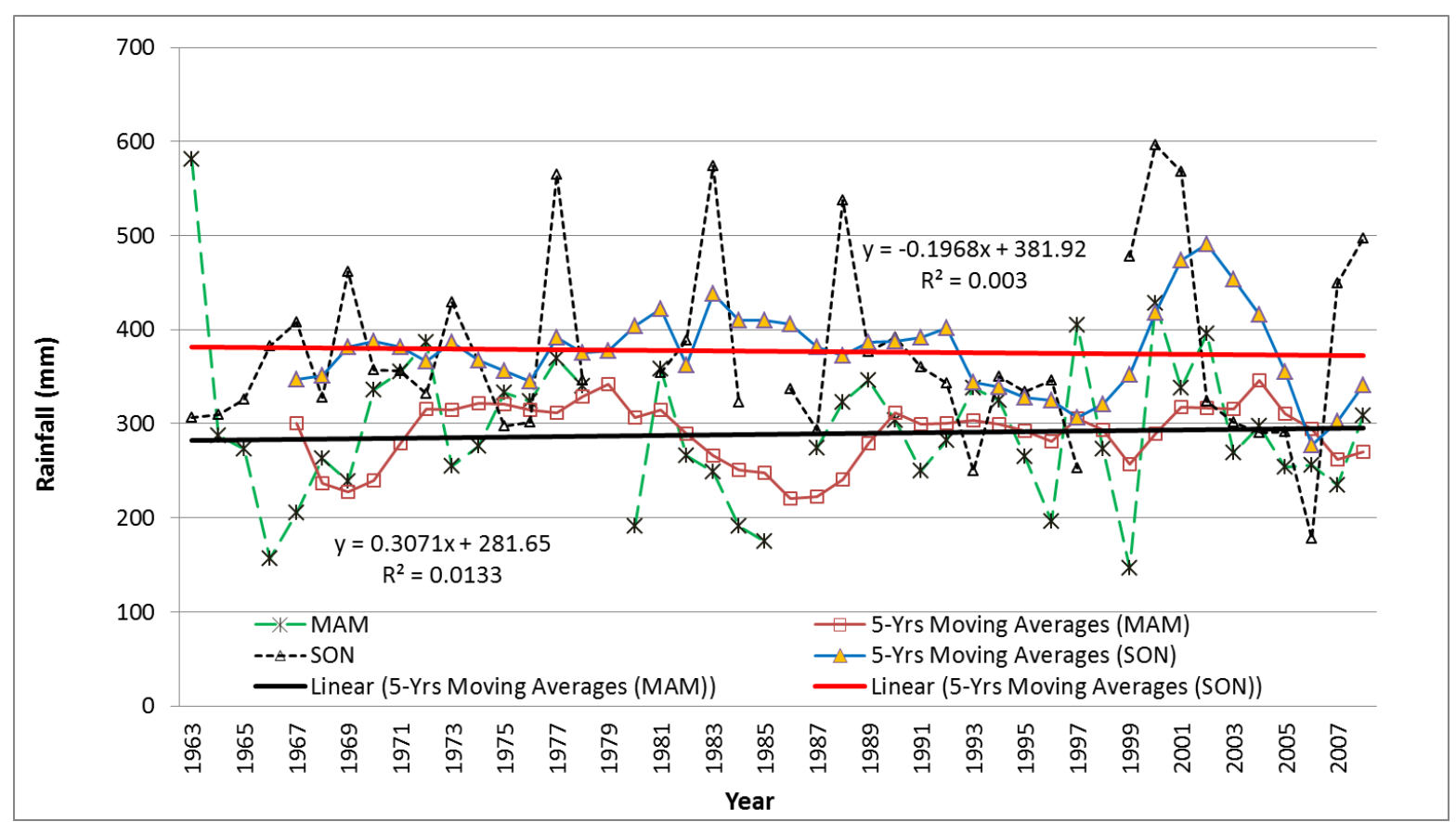

Figure 5. Annual and 5 year moving averages of seasonal rainfall for both MAM and SON fitted with a linear trend lineUganda station in the Lake Victoria Basin.

Despite the linear trend analysis could not reveal a statistical significance in decline or increase in amount of seasonal and annual rainfall, historical records from elder pastoralist (who have stayed in the area for over 30 years) have reported shifts in occurrence of rainfall and its distribution over the year. It is also been revealed that there is increasing rise in temperature as compared to the past. For example, the findings from household survey in Tanzania revealed that $96.7 \%$ of the agro-pastoralist respondents had stated that the rainfall is declining compared with the past periods and that the temperature has increased [13]. It is also been accentuated that there is presently inconsistency in rainfall occurrence. Majority claim that such variability in climate associated with shifts in rainfall patterns in terms of quantity and frequency over the past three decades have had direct consequences on their livelihoods because it has changed the grazing land. 
Using a case in the Uganda study area, analysis for the number of rain-days and the average historical monthly rainfall revealed the concerns posed by the agro-pastoralist. Figure 6(a) and Figure 6(b) present the number of season rain-days over the time, while Figures 7(a)-(c) present a comparison in average historical monthly rainfall for the different periods. The results (Figure 6(a) and Figure 6(b)) revealed that the number of rain-days appear to be declining with time for all seasons. It is also clear that there is a shift in occurrence of rainfall (Figures 7(a)-(c)). The shift is either indicating the increase in rainfall amount in recent times as compared to the past (upward arrow) or a change in rainfall month (left arrow). The pattern of change is very consistent in the three countries, with a shift of one month in recent time (i.e. 1990-2009).

The shift analysis indicate an increase in amount of rainfall (upward arrow) for all stations considered which contradicts the perceived decrease in rainfall amount and rain-days as revealed by both household survey and rain-days analysis using the Uganda case. Such contradiction could be a result of increase in rainfall intensity for any single event of rainfall concentrated in a very narrow time band. According to [14] [15], climate predictions along Lake Victoria region indicate increase in temperature associated with increase in rainfall event in very isolated areas. Furthermore, climate change scenarios using multiple general circulation models show increases in average mean temperature. In Tanzania, the predictions show that the mean daily temperature will rise by $3^{\circ} \mathrm{C}$ $-5^{\circ} \mathrm{C}$ throughout the country and the mean annual temperature will rise by $2^{\circ} \mathrm{C}-4^{\circ} \mathrm{C}$. Further predictions show that areas with bimodal rainfall pattern will experience increased rainfall of $5 \%-45 \%$ and those with unimodal rainfall pattern will experience decreased rainfall of 5\% - 15\% [14] [15].

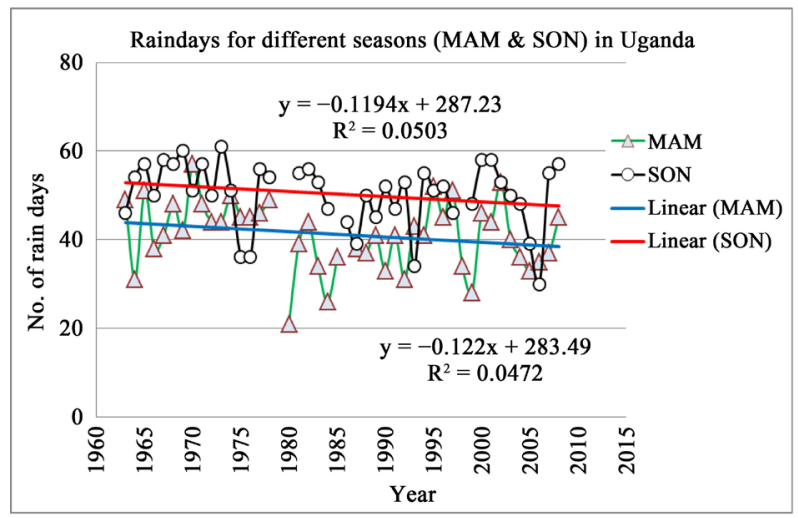

(a)

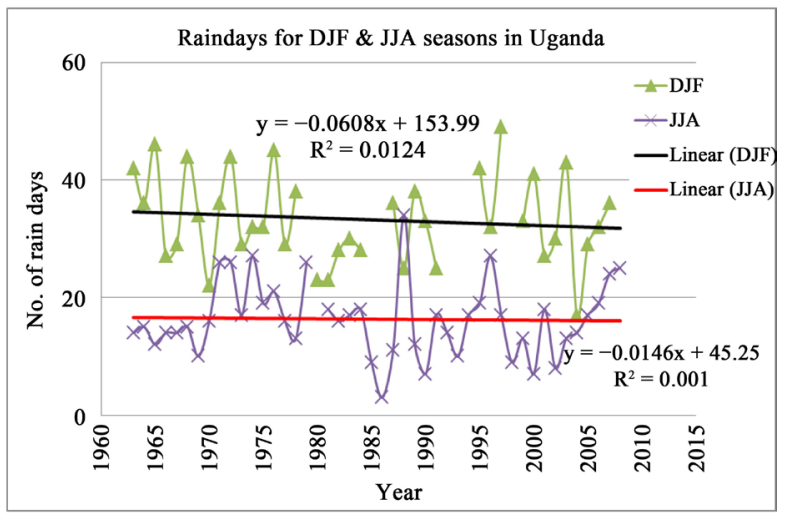

(b)

Figure 6. Rain-days for different seasons for Uganda study station (1963-2010) fitted with a linear trend line.

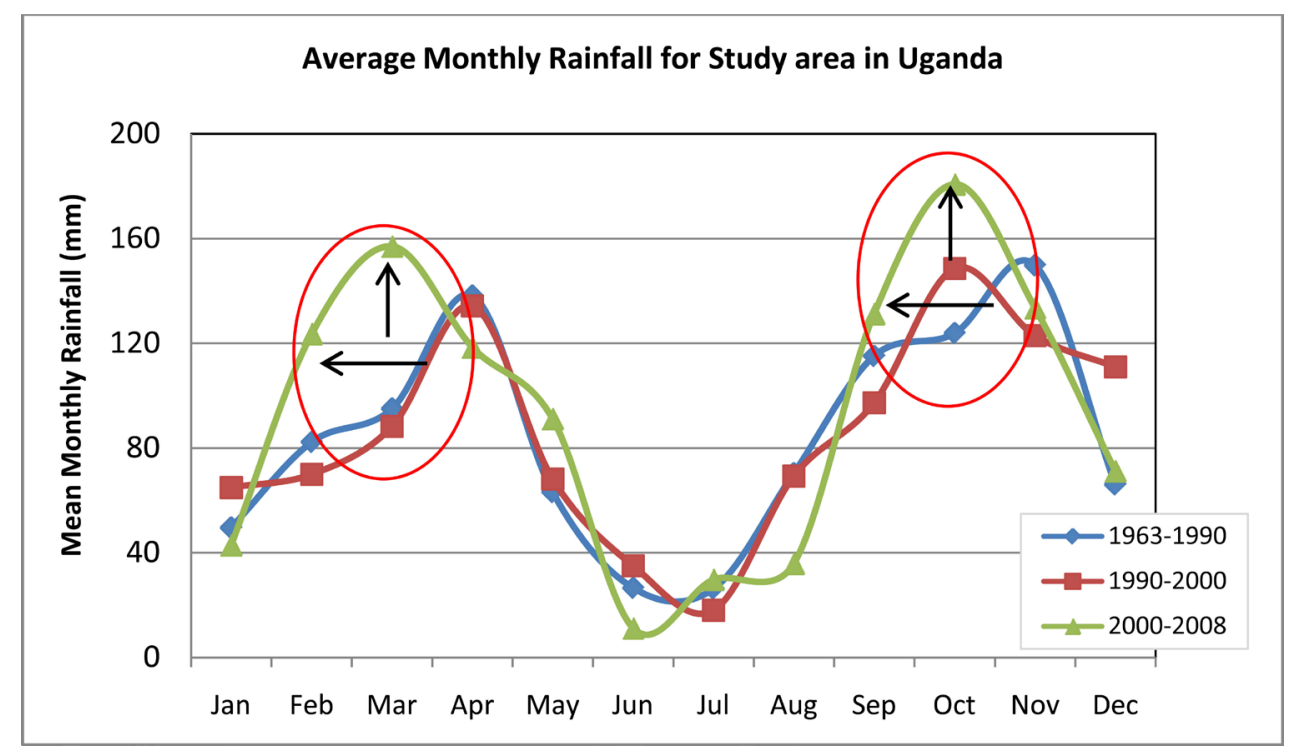

(a) 


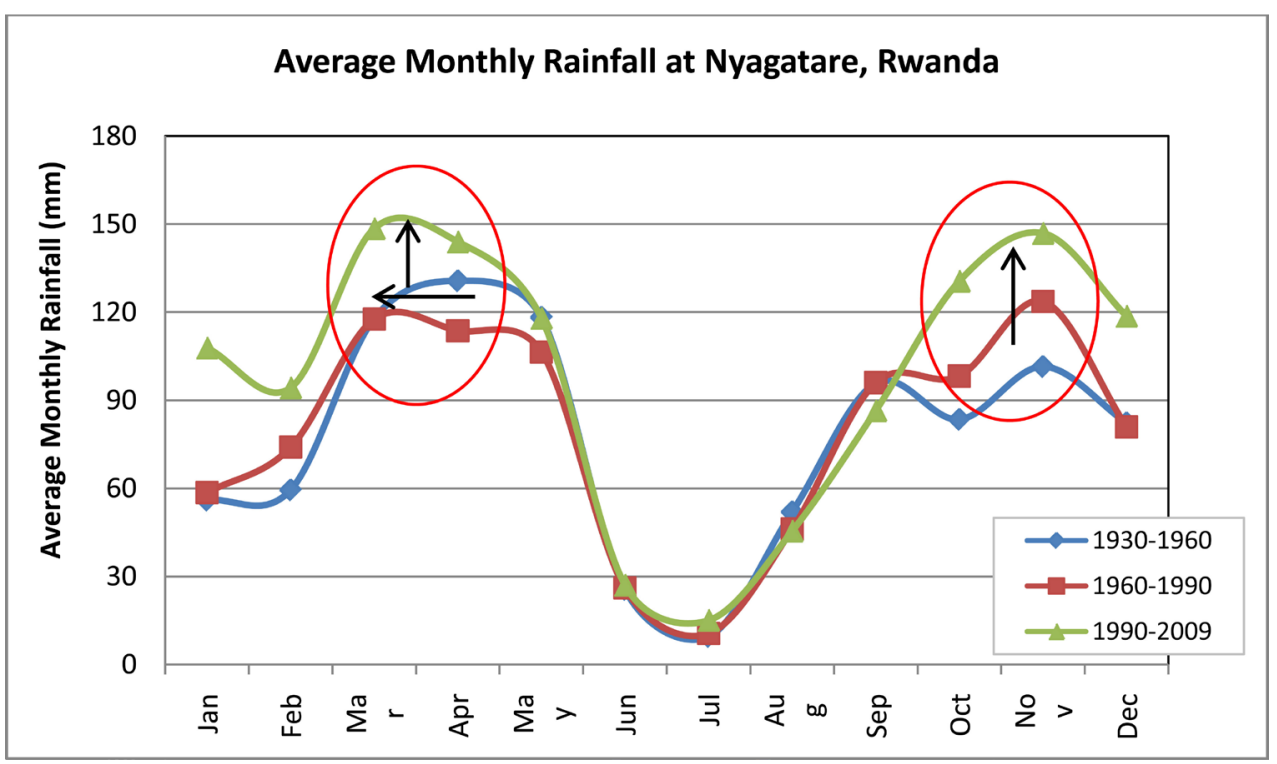

(b)

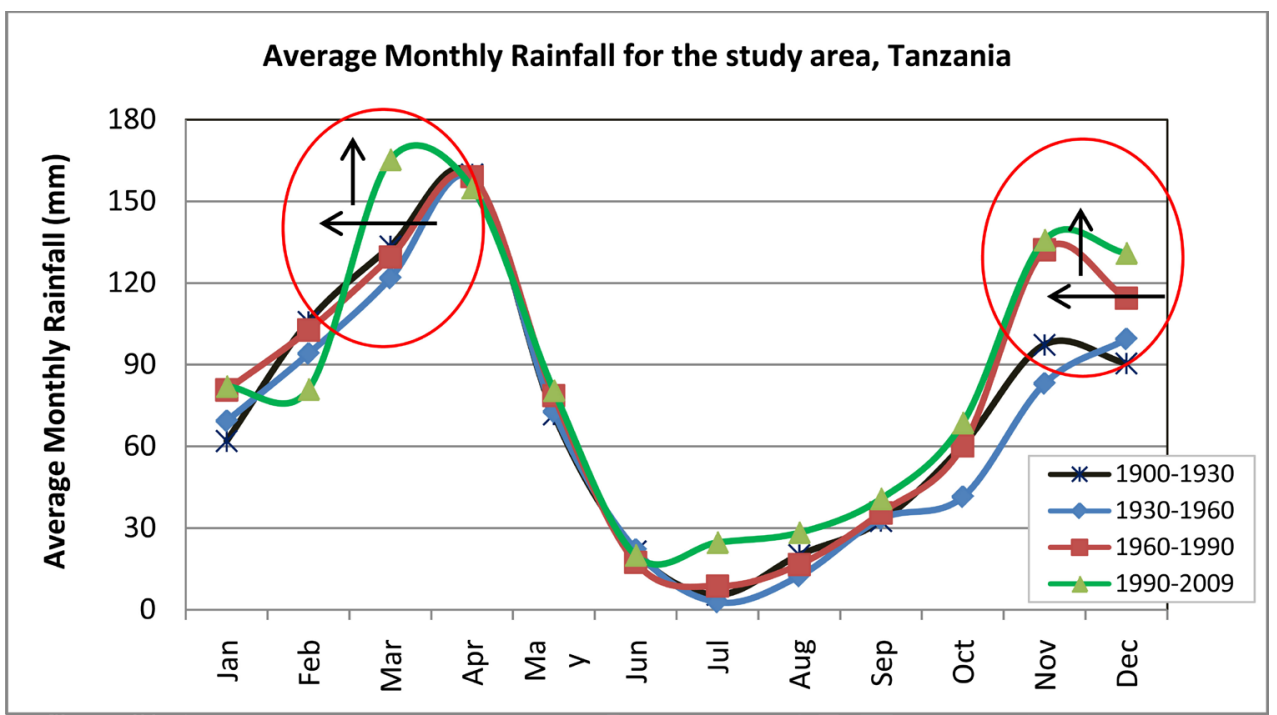

(c)

Figure 7. Average historical monthly rainfall of the study areas (Rwanda, Uganda and Tanzania) in the Lake Victoria Basin for the different data record periods. (Note: the left and up arrows inside the figures indicate a direction of shift with time). Source of climate data: http://sdwebx.worldbank.org/climateportal/.

Temperature analyses are consistent with climate prediction models as revealed in Figure 8 and Figure 9(a), Figure 9(b). The results show a consistent increase in temperature across the study area in the Lake Victoria Basin. The only exception is for Nyagatare area in Rwanda that indicate very limited variations unlike those found in the other two countries (Figure 9(a), Figure 9(b)). According to [16] extreme temperature events constitute climate variability and change; hence the observed variations in climate might be an artefact of temperature rise in the area.

\subsection{Implications of Land Use and Land Cover Change on Beef Cattle Production}

The consequence of consistent conversion of grazing areas in the LVB into other land use types in the past twenty to thirty years is reduction in pasture availability, which is the cheapest and major feed source for ruminant livestock production. Although cattle populations have been on the increase in the same period, it has been 


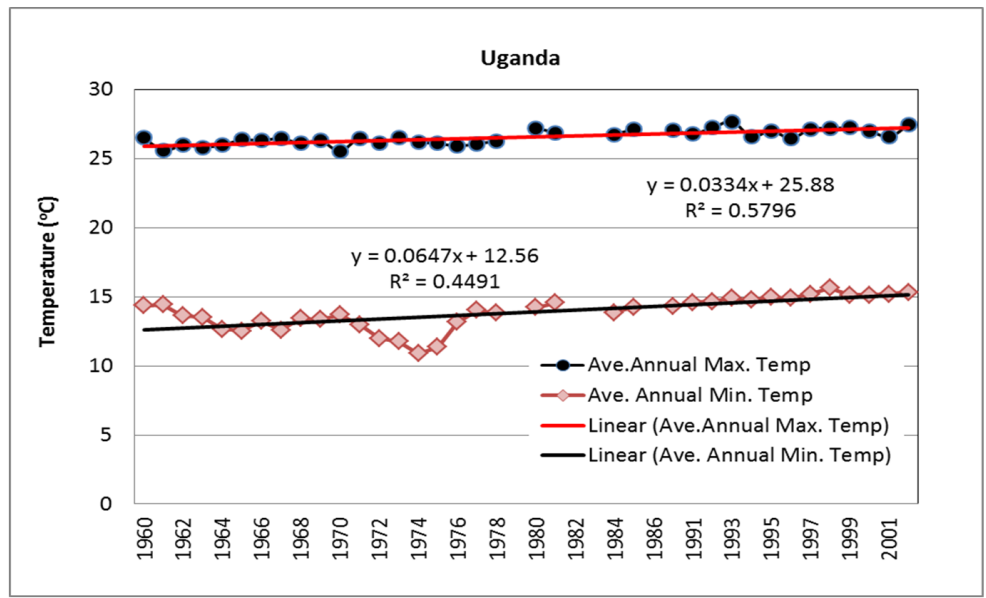

Figure 8. Average annual maximum and minimum temperature amount over time for the study area in Uganda.

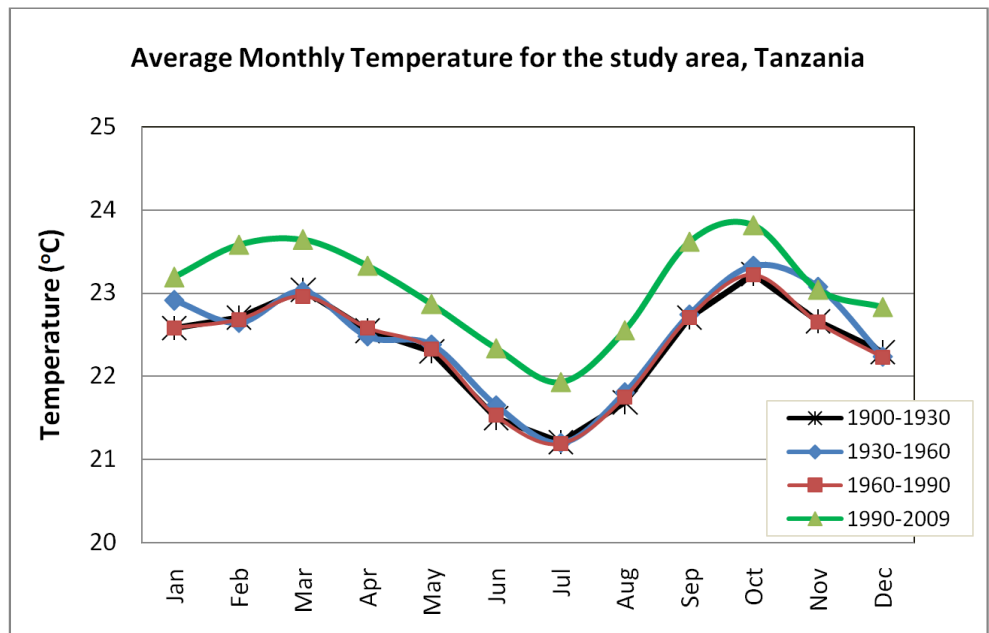

(a)

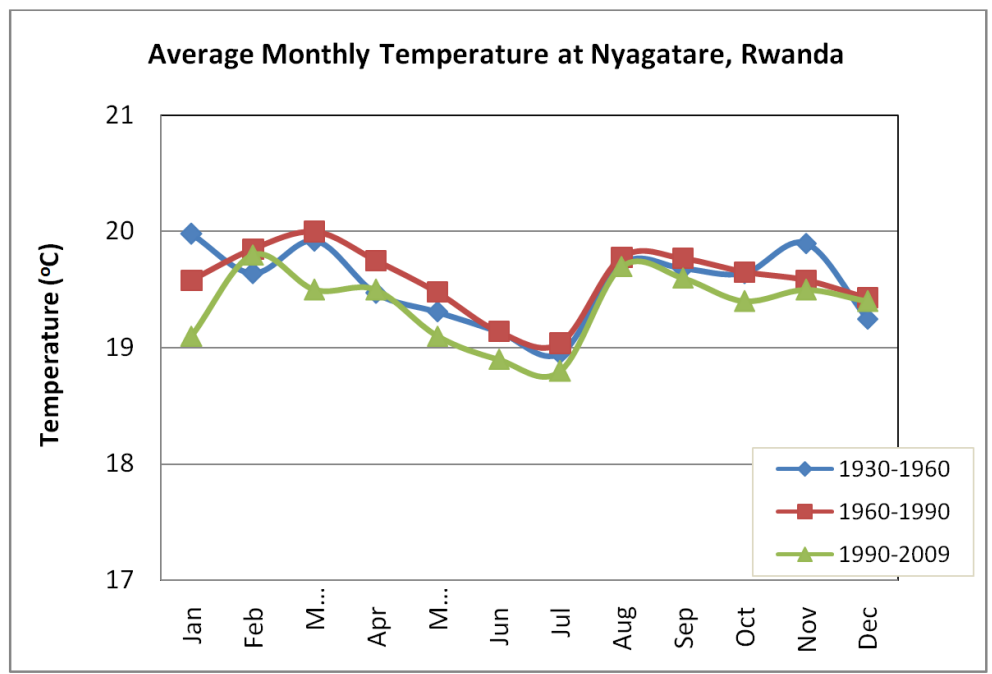

(b)

Figure 9. Average monthly temperature of the study areas (Tanzania and Rwanda) in the Lake Victoria Basin for the different data record periods. Source of climate data: http://sdwebx.worldbank.org/climateportal/. 
largely attributed to the fact that the carrying capacity of available grazing areas had not been attained. The current stocking rates in the LVB reveal that the rangelands are greatly overstocked and overgrazed with degradation leading to bare areas which are already evidenced. Climate variability coupled with a decrease in grazing resources are driving unprecedented forage scarcity which is a major limiting factor to cattle production.

With crop cultivation being a major land use type overtaking grazing lands, the incorporation of crop residues into ruminant feeding areas is a feasible way out to curtail rangeland degradation and increase beef production. However, despite the immense conversion of traditional grazing land into cultivation, there is limited use of crop residues in animal feeding with lack of knowledge to change farmers' behaviour [9]. The current trend will increase pressure on the dwindling grazing resources as new additions of stock to meet livelihood requirements are being done under restrained resources.

One hectare of maize can generate about 7.76 tons dry matter of stover [17]. With animals consuming up to $2.5 \%$ DM of body weight per day of dry forages [18] stover from one hectare of maize can sustain up to three Tropical Livestock Units (TLU) for a year in areas with one cropping season and up to six TLU in areas with two cropping seasons a year provided that farmers can balance the energy and protein requirements of animals with supplements (crop residues, forage legumes, agro processing by-products or commercial supplements).

\subsection{Implications of Climate Variability and Change on Beef Cattle Production}

The climate variability and change analysis has revealed the changes in rainfall and temperature in the Lake Victoria Basin. [19] cautioned that, while climate change is a global phenomenon, people will be differently affected by its local impacts. Among others, change in temperature and precipitation patterns will have a profound impact on the natural resource base worldwide, and on the income and livelihoods of people that depend on these resources. This is now a reality in the Lake Victoria Basin where the resulting effects are more apparent. Discussion with agro-pastoral communities in the three study area of LVB revealed numerous impacts and consequences as a result of climate variability and change Results from the three countries' case studies have revealed the following impacts and consequences (Table 5).

The above findings are consistent previous studies conducted elsewhere in the LVB. For example [20] revealed that livestock production is one of the production systems that are potentially vulnerable to climate variability and change. Their findings revealed significant decrease in pastures leading to low livestock production in terms of calves, milk and meat and that unpredictable rainfall, has resulted into inadequate pastures as compared to previous years. As a result livestock production is locally believed to decline. It was asserted that because of the unfavourable pasture conditions the livestock do not have sufficient feed; they are generally weak and may not breed as efficiently as would do under favourable conditions. Generally, shortage of pastures due to changing climate may result in competition for available land, causing conflict and insecurity [20]. Their study also revealed problems associated with declining water resources, increase in diseases, declining forage productivity and other impacts beyond livestock production.

\section{Conclusions and Recommendations}

The study has revealed that the selected areas in Rwanda, Uganda and Tanzania in the Lake Victoria Basin have changed over the time following land cover manipulations and land use change, coupled with climate variability

Table 5. Revealed impacts and consequences of climate variability and change in the LVB.

\begin{tabular}{|c|c|}
\hline Impact & Consequences \\
\hline 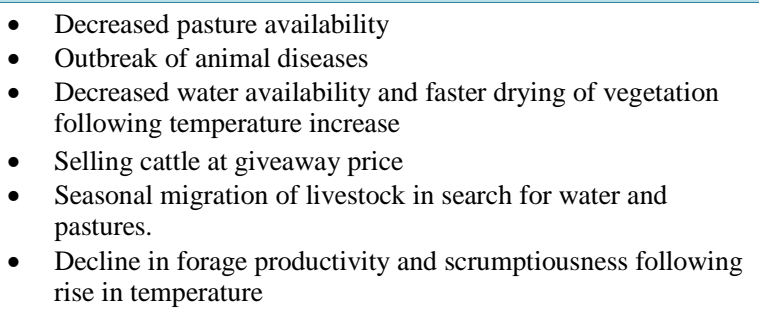 & $\begin{array}{l}\text { - Death of cattle } \\
\text { - Increased conflicts between farmer and pastoralists over } \\
\text { water access } \\
\text { - Low household income and inability to meet family needs } \\
\text { - Migrating or relocating to other regions and causing } \\
\text { destruction to environment }\end{array}$ \\
\hline - Environmental destruction by making holes at a river sand bed & $\begin{array}{l}\text { - Change in river courses and increased sedimentation rates } \\
\text { (e.g. Simiyu River in Tanzania) }\end{array}$ \\
\hline
\end{tabular}


and change. The consequence of consistent conversion of grazing areas in the LVB into other land use types in the past twenty to thirty years is the reduction in pasture availability, which is the cheapest and major feed source for ruminant livestock production. Although cattle populations have been on the increase in the same period, it has been largely attributed to the fact that the carrying capacity of available grazing areas had not been attained. The current stocking rates in the LVB reveal that the rangelands are greatly overstocked and overgrazed with degradation leading to bare areas already evidenced. Climate variability coupled with decreases in grazing resources is driving unprecedented forage scarcity which is now a major limiting factor to cattle production. With crop cultivation, settlement expansion being major land use types overtaking grazing lands, the incorporation of crop residues into ruminant feeding systems is a feasible way out to curtail rangeland degradation and to increase beef cattle production. Since at least three TLU can be added into the production system for every one hectare of cereal cultivated, it can be concluded that the future of beef cattle production in the LVB lies in proper utilization of crop residues from the cultivated area as animal feed. There is therefore a need to educate farmers in order to attain change in behaviour.

\section{Acknowledgements}

This research was funded by VicRES through a project titled” Improving Beef Cattle Productivity for Enhanced Food Security and Efficient Utilization of Natural Resources in the Lake Victoria Basin”.

\section{References}

[1] Kulindwa, A.A.K. (2006) Social and Policy Framework: Context of People and Livelihood. In: Odada, E.O., Olago, D.O. and Ochola, W.O. (Eds.), Environment for Development: An Ecosystems Assessment of Lake Victoria Basin Environment and Socioeconomic Status, Trends and Human Vulnerabilities.

[2] Rutamu (2010) Investment Opportunities in the Dairy Sub-Sector of Rwanda. SNV and IFAD Final Report, 50 p. www.snvworld.org/.../investment_opportunities_dairy_sub-sector_of_rwanda.pdf

[3] Rukazambuga, N.T.D. (2008) Agricultural Innovation and Technology in Africa: Rwanda Experience Coffee, Banana and Dairy Commodity Chains. $37 \mathrm{p}$. http://info.worldbank.org/etools/docs/library/243550/RwandaInnovationStudyreport.pdf

[4] MAAIF and UBOS (2009) Ministry of Agriculture, Animal Industry and Fisheries and Uganda Bureau of Statistics. National Livestock Census Report 2008.

[5] CARE International-Tanzania (2004) Final Report of the Midterm Evaluation. Magu District Livelihood Security Project of Magu District, Mwanza.

[6] Mpofu, N., Mareko, M.H.D. and Makore, J. (1998) The Growth Performance of Crossbred Progeny of Foreign Sire Breeds in Semi-Arid Africa. Proceedings of the 6th World Congress on Genetics Applied to Livestock Production, Bulawayo, 6-12 March 1998, 227-230.

[7] Steinfeld, H., Gerber, P., Wassenaar, T., Castel, V., Rosales, M. and de Haan, C. (2006) Livestock’s Long Shadow. FAO, Rome.

[8] Zziwa, E., Kironchi, G., Gachene, G., Mugerwa, S. and Mpairwe, D. (2012) The Dynamics of Land Use and Land Cover Change in Nakasongola District. Journal of Biodiversity and Environmental Sciences, 2, 61-73.

[9] Mugerwa, S., Mpairwe, D., Zziwa, E., Namutebi, S. and Peden, D. (2012) Improving Livestock Water Productivity in Semi-Arid Ecosystems: Restoration of Pasture on Degraded Bare Surfaces. Novus Natural Science Research, 1, 1-13.

[10] Siwa, E. (2013) Rangeland Monitoring and Assessment for Improved Beef Cattle Production under Changing Climatic Conditions Using Remote Sensing and GIS: A Case of Ilemela and Magu Districts in the Lake Victoria Basin, Tanzania. MSc. Dissertation, Ardhi University, Tanzania.

[11] Laswai, G.H., Kashaigili, J.J., Zziwa, E., Musana, B.S., Mpairwe, D., Kadigi, R.M.J., Ebong, C., Mugasi, S.K., Laswai, G.H. and Mupenzi, M. (2015) Improving Beef Cattle Productivity for Enhanced Food Security and Efficient Utilization of Natural Resources in the Lake Victoria Basin. VicRes Annual Project Report.

[12] Salmi, T., Määttä, A., Anttila, P., Ruoho-Airola, T. and Amnell, T. (2002) Detecting Trends of Annual Values of Atmospheric Pollutants by the Mann-Kendall Test and Sen's Slope Estimates-The Excel Template Application MAKESENS, Publications on Air Quality No. 31, Report Code FMI-AQ-31, Finnish Meteorological Institute, 35 p.

[13] Laswai, E. (2014) Evaluation of Coping Strategies of Pastoral Communities to the Effects of Climate Variability in Magu and Ilemela Districts, Tanzania. MSc. Dissertation, Sokoine University of Agriculture, Tanzania.

[14] United Republic of Tanzania_URT (2005) Initial National Communication under the United Nations Framework 
Convention on Climate Change (UNFCCC), Vice President's Office, Dar es Salaam.

[15] United Republic of Tanzania_-URT (2007) National Adaptation Programme of Action (NAPA). Division of Environment, Vice President's Office, Dar es Salaam.

[16] Kashaigili, J.J., Levira, P., Liwenga, E. and Mdemu, M.V. (2014) Analysis of Climate Variability, Perceptions and Coping Strategies of Tanzanian Coastal Forest Dependent Communities. American Journal of Climate Change, 3, 212222. http://dx.doi.org/10.4236/ajcc.2014.32020

[17] Barten, T.J. (2013) Evaluation and Prediction of Corn Stover Biomass and Composition from Commercially Available Corn Hybrids. Ph.D. Dissertation, Iowa State University, Ames.

[18] Ryan, S.M., Unruh, J.A., Corrigan, M.E., Drouillard, J.S. and Seyfert, M. (2007) Effects of Concentrate Level on Carcass Traits of Boer Crossbred Goats. Small Ruminant Research, 73, 67-76. http://dx.doi.org/10.1016/j.smallrumres.2006.11.004

[19] IPCC (2007) Climate Change 2007: Impacts, Adaptation and Vulnerability. Contribution of Working Group II to the Fourth Assessment Report of the Intergovernmental Panel on Climate Change (IPCC). Cambridge University Press, Cambridge.

[20] Kangalawe, R.Y.M. and Lyimo, J.G. (2013) Climate Change, Adaptive Strategies and Rural Livelihoods in Semiarid Tanzania. Natural Resources, 4, 266-278. http://dx.doi.org/10.4236/nr.2013.43034 